\title{
Simulation of surface runoff in Karaj dam basin, Iran
}

\author{
Maryam Alipour ${ }^{1} \cdot$ Majid Hosseini $^{2} \mathbb{C}$
}

Received: 26 March 2018 / Accepted: 2 August 2018 / Published online: 16 August 2018

(c) The Author(s) 2018

\begin{abstract}
A major part of the Iranian capital drinking water is supplied from Karaj reservoir $100 \mathrm{~km}$ northwest of Tehran. This reservoir collects water from $849 \mathrm{~km}^{2}$-catchment which is undergoing accelerated changes due to deforestation and urbanization. The main objective of this study is to develop a catchment modeling platform which translates ongoing land-use changes, soil data, precipitation and evaporation into surface runoff of the river discharging into the reservoir: Soil and Water Assessment Tool, SWAT, model along with hydro-meteorological records of 1997-2011. A variety of statistical indices were used to evaluate the simulation results for both calibration and validation periods; among them, the robust Nash-Sutcliffe coefficients were found to be 0.58 and 0.62 in the calibration and validation periods, respectively. This project has developed a reliable modeling platform with the benchmark land physical conditions of the Karaj dam basin.
\end{abstract}

Keywords SWAT model $\cdot$ Land-use change $\cdot$ Rainfall-runoff modeling $\cdot$ Sensitivity analysis $\cdot$ SWAT-CUP $\cdot$ SUFI-2

\section{Introduction}

More detail information on the status of rainfall runoff increases decision-making power on future programs for watershed managers of natural resources for sustainable development. Recently, rainfall-runoff models are widely used by hydrologists to simulate watersheds runoff and play a key role in water resources management (Bilondi et al. 2013). On the other hand, several programs and techniques have been developed to reduce uncertainty of parameters to get best fit of parameters in the hydrological modeling (Singh and Dutta 2016). These hydrological models are utilized in assessing the land-use change, effects of climate change, water quantity and quality of river flow, forecasting of flood, development and protection of water resources, integrated management of water components and most of

Majid Hosseini

mjhossaini@gmail.com

Maryam Alipour

Maryam.j.alipour@gmail.com

1 Department of Watershed and Rangeland, Faculty of Natural Resources, Sari Agricultural Sciences and Natural Resources University, P.O. Box 587, Mazandaran, Iran

2 Soil Conservation and Watershed Management Research Institute (SCWMRI), Agricultural Research, Education and Extension Organization (AREEO), P. O. Box 13445-1136, Tehran, Iran the water resource management measures (Singh and Woolhiser 2002, 2016; Wurbs 1998). In most of the basins that require water resource planning, there is a lack of hydrometric stations for surface runoff measurement, or the data of measurement stations are incomplete; it is also unlikely to have measurement stations in all regions in the near future. Hydrological models, therefore, can evaluate the obtained runoff from precipitation in basins with no or incomplete surface runoff data with minimum cost and time by simulating the rainfall-runoff process.

Soil and Water Assessment Tools (SWAT) is one of the most popular hydrological models for runoff simulation in the world. The SWAT model is a continuous and distributed hydrological model to perform at the watershed scale (Hosseini and Ashraf 2015; Krysanova and Srinivasan 2015). This model introduced by Arnold et al. (1998) and further developed by Arnold and Fohrer (2005) can simulate hydrological processes in basins of small, medium and large scales. This model can be run on monthly, daily and hourly time scales and can simulate all components of water balance (Arnold et al. 1998).

Several studies have been conducted on different basins using SWAT model. This model has been widely used to land-use change effect assessment (Shen et al. 2010; De Girolamo and Lo Porto 2012; Yang et al. 2012; Du et al. 2013; Huang et al. 2013; Niu and Sivakumar 2014), sediment prediction (Shen et al. 2010), climate change 
(Andersson et al. 2006; Zhang et al. 2012; Huang et al. 2015), water quality (Debele et al. 2008; Zhang et al. 2011) and simulation of evapotranspiration (Wang et al. 2006). Many computer programs have been developed by hydrologists for parameters uncertainty analysis in river basin model, such as, generalized likelihood uncertainty estimation (GLUE; Beven and Binley 1992), sequential uncertainty fitting (SUFI-2; Abbaspour et al. 2004), parameter solution (ParaSol; Van Griensven and Meixner 2006) and Markov chain Monte Carlo (MCMC; Kuczera and Parent 1998; Vrugt et al. 2008).

SWAT model was selected among fifteen hydrological models to separate water components, which successfully fulfilled the annual and monthly water budget estimation as well as suspended sediment yield in the Taleghan catchment during 1987-2007, with a reliable accuracy (Hosseini 2010). The SWAT-CUP (Abbaspour et al. 2007b) is a computer program that links the sequential uncertainty fitting (SUFI-2) algorithm to SWAT model. Up to now, researchers used SUFI-2 algorithm for model calibration and uncertainty analysis of parameters of SWAT model as a popular method in the world. Fukunaga et al. (2015) investigated the application of the SWAT hydrologic model in a tropical watershed at Brazil. Narsimlu et al. (2015) in the Kunwari river basin applied SUFI-2 algorithm for model calibration, sensitivity and uncertainty analysis for 19 years from 1987 to 2005 . Nyeko (2015) assessed the capabilities and limits of SWAT model in modeling watershed that has limited field and hydrologic data for possible use in water resources management. Krysanova and Srinivasan (2015) assessed five projects of different applications of SWAT covering the impacts of land cover change, climate change and combined impacts of climate change and human activities in water management. Vilaysanea et al. (2015) applied SWAT model to test the capability of the model for predicting stream flow and used SUFI-2 algorithm for calibration and uncertainty analysis in Xedone river basin. Lin et al. (2015) in their study found out the effects of land-use and land cover changes on runoff response using SWAT model. They used two different land-use scenarios (1985 and 2006, with reduced forest and increased cropland and urbanized area) in Jinjiang catchment. Hosseini et al. (2012) studied the effects of land-use changes on the water balance components in Taleghan basin using SWAT model. Both SUFI-2 and Parasol programs were used to calibrate and verify the model using the data from the period 1987-2007. A comparison of the water budget components performed by this model in Taleghan catchment from 1995 to 2004 using the three land-use maps of 1987, 2001 and 2007 by Hosseini and Ashraf (2015) showed reliable results for both calibration and validation periods.
The main objective of this study is to perform possibility of the SWAT model and SUFI-2 algorithm for runoff simulation of the study area, which will contribute to the reservation of natural resources in the Karaj dam basin.

\section{Materials and methods}

\section{Study area}

Karaj dam basin is located in the southern slopes of the Mountain Alborz between the geographical coordinate's longitude $51^{\circ} \mathrm{E}-51^{\circ} 21^{\prime} \mathrm{E}$ and latitudes $35^{\circ} 30^{\prime} \mathrm{N}-36^{\circ} 6^{\prime} \mathrm{N}$ (Fig. 1). The area of this basin is 84,894 hectares and average annual water flow for Karaj Dam is 472 million cubic meters. The average daily discharge is estimated $154.54 \mathrm{~m}^{3} \mathrm{~s}^{-1}$. There are ten hydrometry stations to measure discharge in the study area. The Sira hydrometry station, located above the Karaj dam, selected to runoff simulation.

\section{Description the SWAT model}

Soil and Water Assessment Tools (SWAT) is a physically based model for assessing the impact of management and climate on water supplies, sediment and agricultural chemical yields in catchments (Narsimlu et al. 2015). This model is a basin-scale, spatially distributed watershed delivery model developed by the Agricultural Research Service (ARS) at the US Department of Agriculture (USDA). Its purpose is to simulate water, sediment and chemical yields on large river basins and possible impacts of land use, climate changes and watershed management. Output from SWAT can be daily, monthly or yearly, but in all cases is based on a daily model time step. SWAT can be applied in watersheds up to several $1000 \mathrm{~s}$ of $\mathrm{km}^{2}$, using a two-level disaggregation scheme. Preliminary sub-basin identifications are carried out based on topographic criteria, followed by further discretization using land use and soil type. The physical properties inside each sub-basin are then aggregated with no spatial significance.

In SWAT, a catchment is divided into multiple sub-catchments with hydrologic response units (HRUs) that consist of homogeneous land use, management, topographic, and soil characteristics (Abbaspour et al. 2007a). SWAT-CUP is a computer program that provided sensitivity analysis, calibration, validation, and uncertainty analysis of SWAT models (Abbaspour et al. 2007b).

The hydrology model is based in a water balance equation, comprising surface runoff, precipitation, evapotranspiration, infiltration and sub-surface runoff. Potential evapotranspiration is estimated using either the Priestley or Taylor (1972) or the Penman-Monteith (Monteith 1965) methods.

The soil profile is represented by up to 10 soil layers, a shallow aquifer and a deep aquifer. When the field capacity 


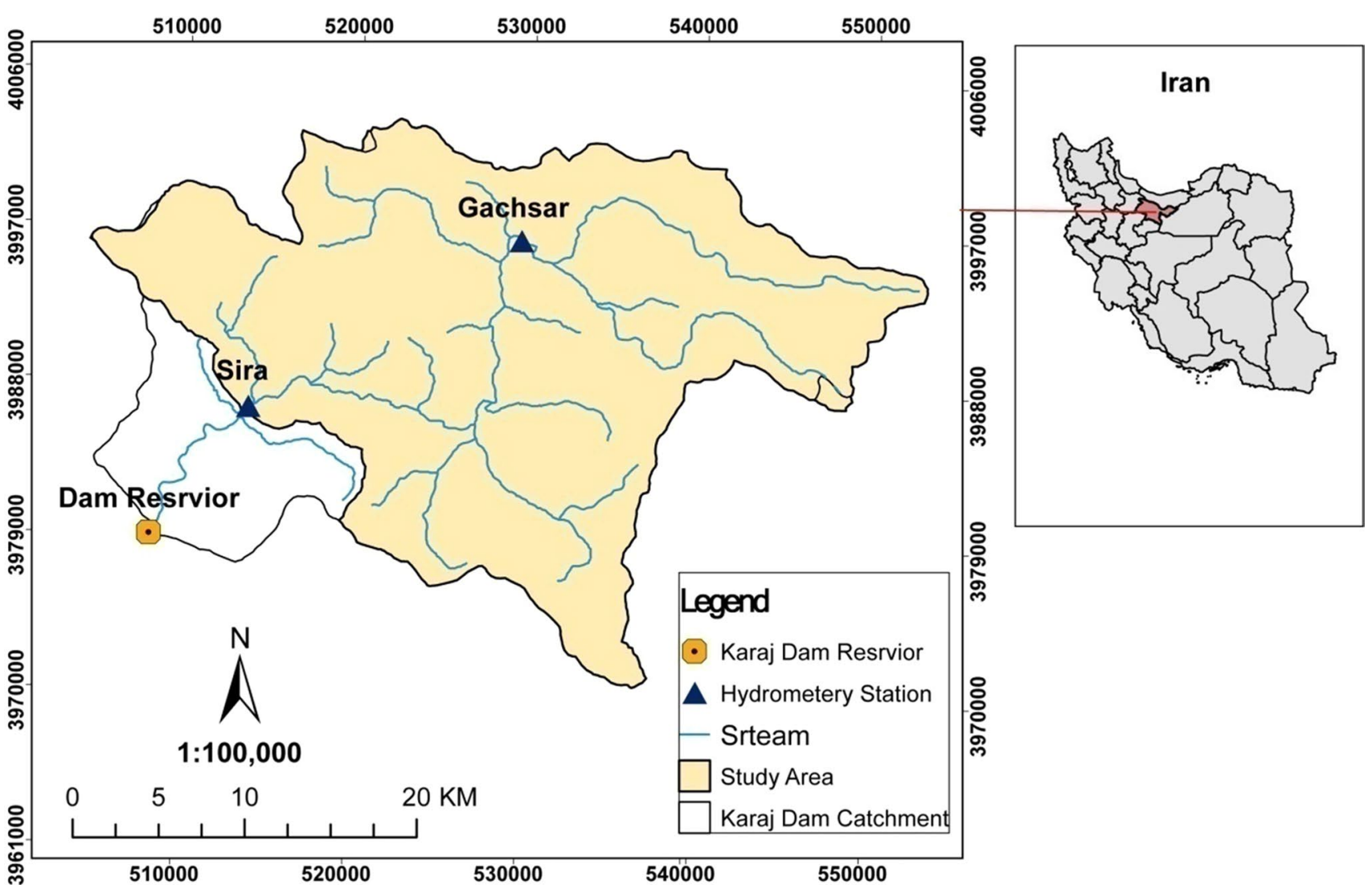

Fig. 1 Location of Karaj dam watershed

in one layer is exceeded, the water is routed to the lower soil layer. If this layer is already saturated, lateral flow occurs. From the bottom soil layer, percolation goes into the shallow and deep aquifers. Water reaching the deep aquifer is lost, but in turn flow from the shallow aquifer due to deep aquifer saturation that is added directly to the sub-basin channel.

Surface runoff is computed by the SCS curve number method (Arnold et al. 1990) and is therefore a non-linear function of precipitation and a retention coefficient. Once all hydrological processes are calculated for a homogeneous part of the sub-basin, the resulting flows are considered to contribute directly to the main channel. SWAT includes a routing module based on the Routing Outputs to Outlet model (ROTO; Arnold et al. 1990), which takes into account the connectivity of the river network.

\section{Description the SUFI-2 algorithm}

A common factor in almost all the published papers is the calibration/validation and uncertainty analysis of the models (Abbaspour et al. 2018). In SUFI-2, parameters uncertainty accounts for all sources of uncertainties. These sources include variables (e.g., rainfall), the conceptual model, model parameters and measured data. To evaluate such uncertainties, SUFI-2 offers two criterion factors, the P-factor and the R-factor. The P-factor indicates the percentage of measured data bracketed by the $95 \%$ prediction uncertainty (95PPU), whereas the R-factor calculates the average thickness of the 95PPUb and divided by the standard deviation of the measured data. Theoretically, the value of the P-factor ranges from 0 to $100 \%$, while that of the $\mathrm{R}$-factor ranges from 0 to infinity. A P-factor of 1 and R-factor of zero indicate a simulation that exactly complies with measured data.

\section{Input data}

Meteorological data with topography, soil and land-use maps are prepared to simulate model. Digital elevation model with resolution 90 meters is used to create topographic data (Fig. 2). Twenty-one hydrologic sub basins were identified in study area. SWAT model needs soil-type and land-use properties to simulate hydrological parameters within each sub-basin (Winchell et al. 2009).

The volume of surface runoff is simulated using the curve number $(\mathrm{CN})$ method. This method was created by Soil Conservation Service (USDA 1972) which calculates surface runoff as a function of soil type, slope, initial soil humidity and management practices(Neitsch et al. 2011). The 


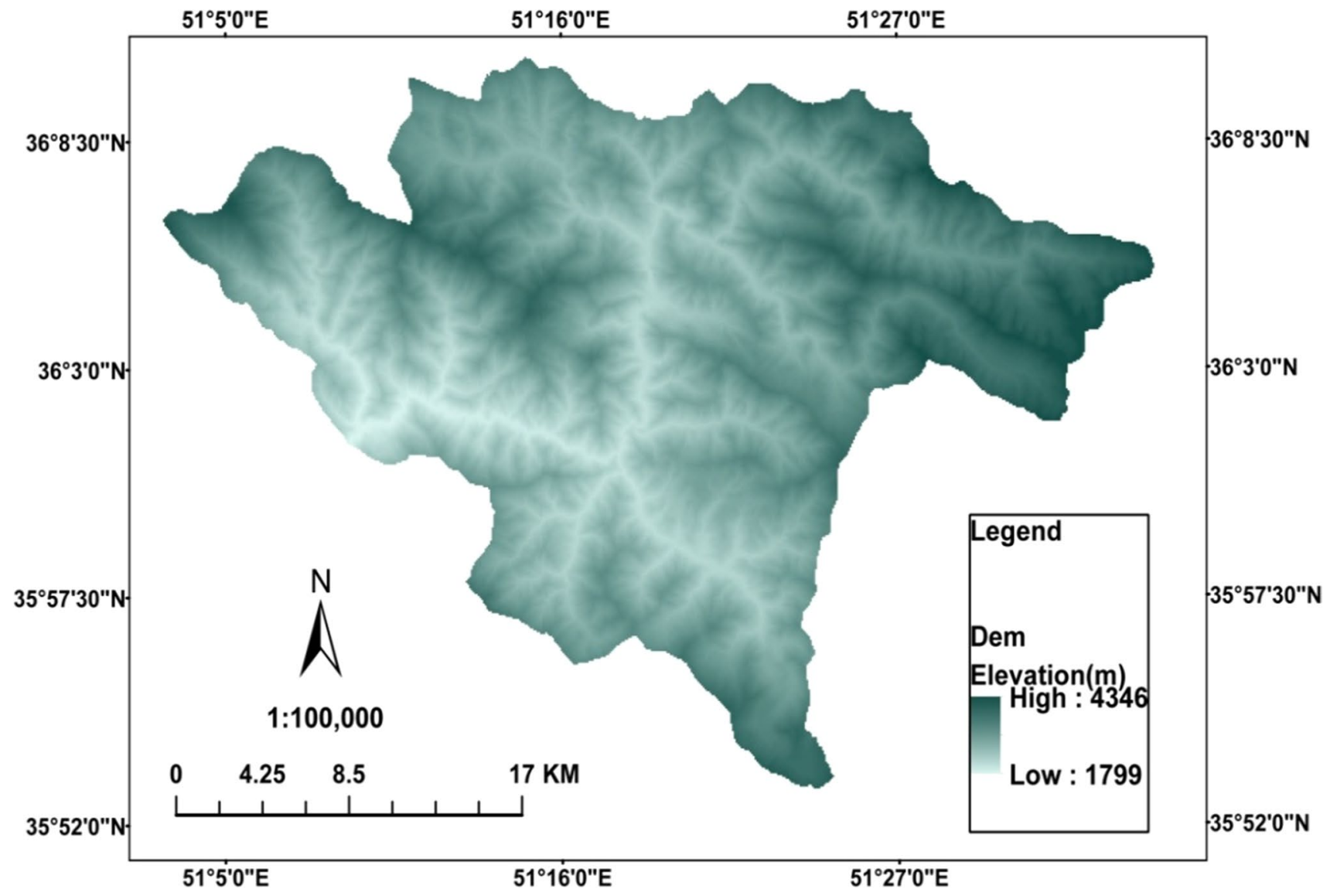

Fig. 2 Digital elevation model (DEM) of Karaj basin

evapotranspiration potential is determined using the Penman-Monteith equation and is corrected for the soil cover and simulated plant growth to get the real evapotranspiration rate (Neitsch et al. 2011; Monteith 1965).

The soil type classified into four classes by the FAO (1997) is presented in Fig. 3. The land-use map provided by SCWMRI (2002) is illustrated in Fig. 4.

The climatic data including daily precipitation, maximum and minimum temperature, relative humidity, solar radiation and wind speed were obtained from the Karaj meteorological station. The data used were for the period January 1 , 1997-December 30, 2011.

\section{Performance evaluation of the model}

The performance of the model was evaluated by visual and statistical comparison of the measured and simulated data. The graphical technique provided an initial general overview (American Society of Civil Engineers 1993). Interpretation of the hydrograph first focused on the peak flows and then on the base flow. There are no existing standards describing the range of values of the statistical parameters that would show acceptable performance of the model (Loague and Green 1991). In this study, seven criteria including $R^{2}$, NSE, PBIAS, RMSE, RSR, P-factor and R-factor are applied to analyze the model (Table 1). American Society of Civil Engineers (1993) has highlighted the Nash-Sutcliffe efficiency coefficient (NSE) (Nash and Sutcliffe 1970) among the various statistical parameters to evaluate hydrological models.

The P-factor (percentage of measured data bracketed by the $95 \%$ prediction boundary) is often named 95PPU (Percentage Prediction Uncertainty). The 95PPU is calculated at the $2.5 \%$ and $97.5 \%$ levels of the cumulative distribution of an output variable obtained through Latin hypercube sampling (Abbaspour 2011). The range of the $\mathrm{P}$-factor varies from 0 to 1 , with values close to 1 indicating good fitness between simulated and observed values (Yang et al. 2008a, b).

Another measure quantifying the strength of a calibration and uncertainty analysis is the R-factor, which is the average thickness of the 95PPU band divided by the standard deviation of the measured data. The calibrated parameter ranges can be generated with an acceptable value of the R-factor and P-factor. 


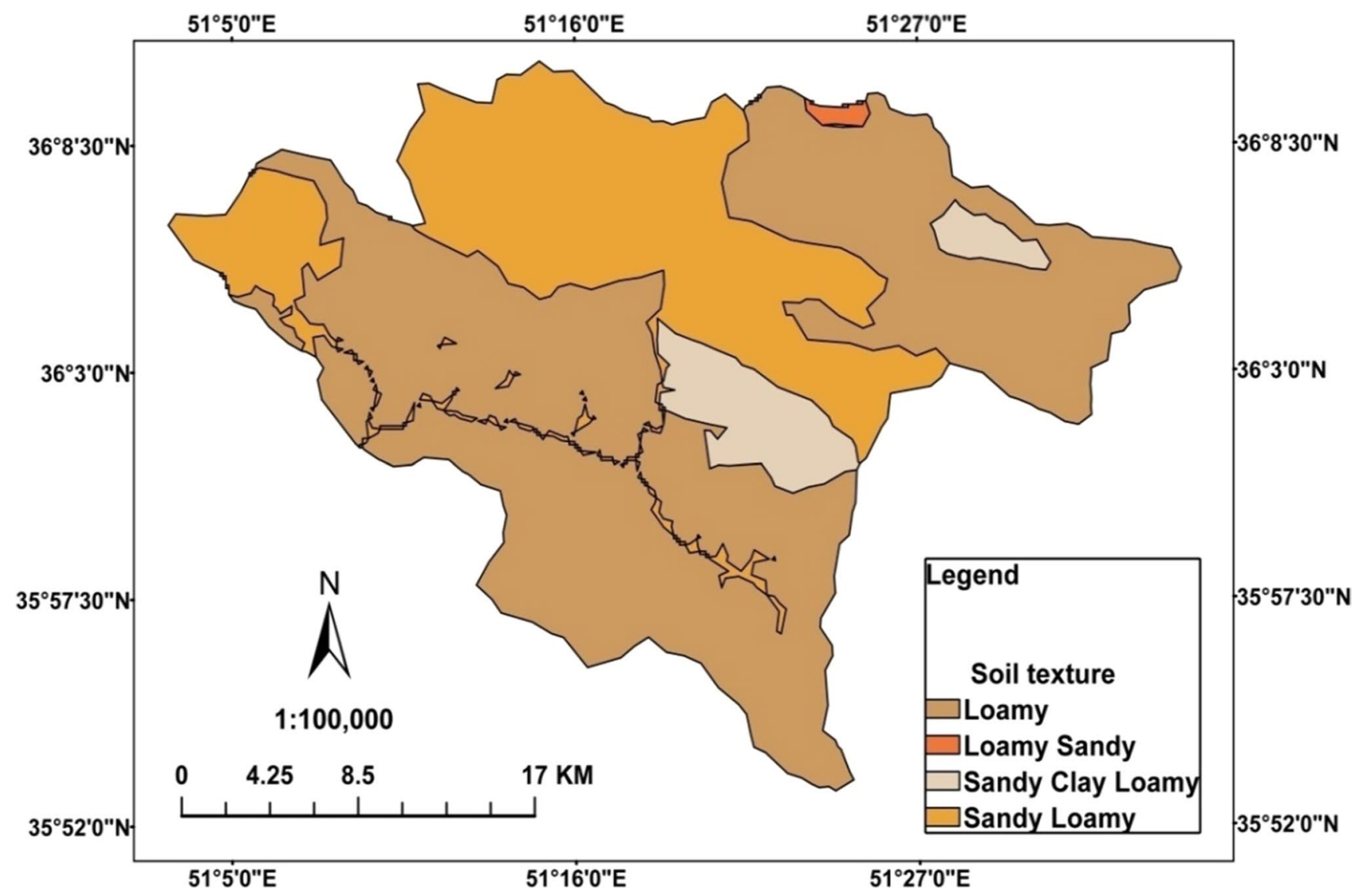

Fig. 3 Distribution of soil classes within Karaj basin

\section{Results and discussion}

\section{Sensitivity analysis of the model parameters}

The sensitivity analysis procedure employed measurement data for the period January 1, 1997-December 30, 2011, to evaluate the fit between the measured and modeled time series data. This enabled the identification of the parameters that were influenced by the characteristics of the hydrographic basin, and those to which the model was most sensitive. Evaluation was then made of the way in which adjusting the value of a parameter affected the model output, in order to identify parameters that might improve the characteristics of the model (Veith and Ghebremichael 2009). Sensitive parameters were calculated using the SUFI-2 algorithm and SSE (sum of square errors) equation between the measured and simulated daily runoff data.

The parameters used for the flow were selected based on the experience in the study area. The initial simulation to determine the sensitivity of the model to different parameters was performed using default parameter values. The values were then varied within upper and lower limits established according to the characteristics of each parameter, using three methods. In the first procedure, the initial value of the parameter is modified by adding an increment. The second method consists of multiplying the initial value by a set amount. In the third method, the initial value is substituted by a different value (Van Griensven et al. 2007).

The sensitivity of the model to a parameter is determined using the percentage difference between the output values of the objective function for simulations performed immediately before and after changing the value of a parameter (Veith and Ghebremichael 2009). A higher t-stat value indicates greater sensitivity for a given parameter.

Thirty-five parameters selected for sensitivity analysis that eight parameters were more sensitive for simulation of the flow (Table 2). These parameters were CN2, ALPHA BF, CH_K2, ESCO, CH_N2, REVAPMN, GW_REVAP and SOL_BD.

\section{Calibration and validation of the parameters}

This research passed through three stages which are as follows: (1) the setup (also known as warm-up) period from 1997 till the end of the year 1999 (3 years), (2) the 


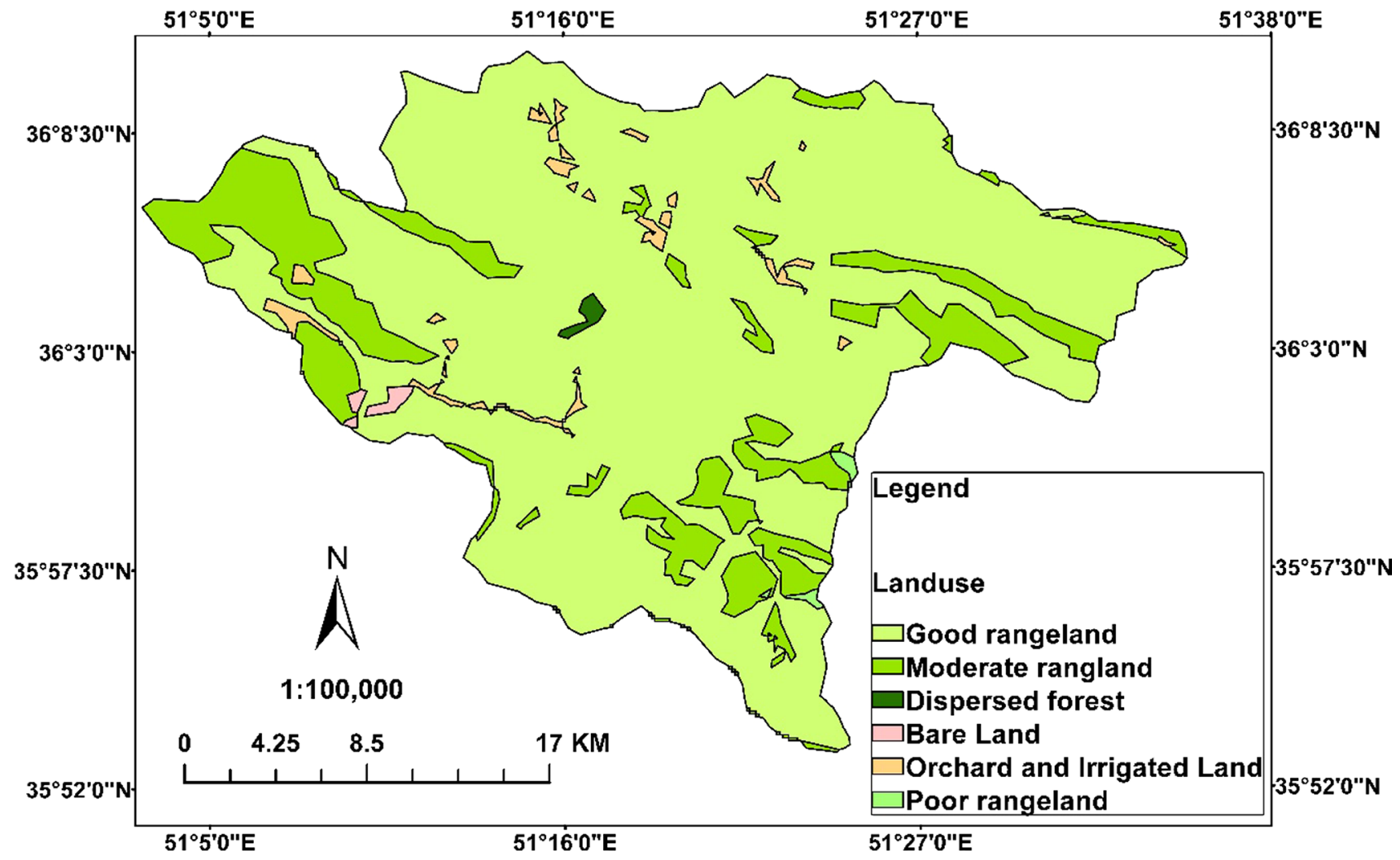

Fig. 4 Land-use map of Karaj basin

calibration period which extended from the beginning of the year 2000 to the end of the year 2006 (7 years), and (3) a validation step covering the period 2007 to the end of the year 2011 (5 years). Usually in modeling, few initial years are selected for setup or warm-up of the model. In general, one-third and two-thirds of the original data sets are selected for model calibration and validation, respectively. Visual analysis of hydrographs shows overestimating of peak runoff with slightly wide uncertainty band (95PPU). Simulated runoff closed to observe one by selecting proper range of sensitive parameters.

The results of calibration period were obtained with four iterations and 500 runs during 2000-2006 (Fig. 5). The calibrated ranges of parameters were performed by model during validation period from 2007 to 2011 (Fig. 6). The results demonstrated that the performance of the calibrated and validated model was satisfactory, with NSE $>0.75, R^{2}>0.5$, PBIAS $< \pm 10$, RMSE $\leq(\mathrm{SD} / 2)$, and $0.06 \leq \mathrm{RSR} \leq 0.70$. Main statistical criteria in calibration periods show $R^{2}$, $\mathrm{P}$-factor, R-factor and NSE are $0.58,0.36,0.36$ and 0.57 , respectively. This analysis shows $0.62,0.63,0.49$ and 0.59 in validation period, respectively (Table 3 ). Coefficient of determination $\left(R^{2}\right)$ and Nash-Sutcliffe efficiency coefficient (NSE) show a reliable correlation between observed and simulated values in both calibration and validation periods.
Statistical analyses are used to evaluate the simulation accuracy of the model performance. The observed and estimated mean monthly discharge at Sira hydrometry station in calibration and validation periods is plotted in Fig. 7a, b.

The results obtained for the statistical criteria demonstrated that the model was able to describe the hydrological processes in the watershed of the Karaj River.

\section{Conclusion}

Many urban and rural societies within Karaj River catchment are dependent on surface water resources. The longterm fluctuation in surface flow may have serious impacts on the daily lives of upstream residents as well as the reservoir and the capital residents in both terms of flooding and yield. SWAT model reproduced surface runoff in Karaj River reliably for both calibration and validation periods using the entire records of years 1997-2011. Seven main statistical criteria including $R^{2}$, NSE, PBIAS, RMSE, RSR, P-factor and R-factor are used to evaluate the modeling results with the observed records of stream flow with minimum uncertainty. The use of sensitivity analysis enabled the identification of the most important parameters required to model the hydrological processes in the Karaj 
Table 1 Criteria for evaluating the performance of the hydrological model and their corresponding classifications

\begin{tabular}{|c|c|c|c|}
\hline Statistical criterion & Ranges of values & Classification of performance & References \\
\hline $\begin{array}{l}\text { Coefficient of determination } \\
R^{2}=\left[\frac{\sum_{1}^{n}\left(O_{i}-\bar{O}\right)\left(S_{i}-\bar{S}\right)}{1} \frac{1}{\left(\sum_{1}^{n}\left(O_{i}-\bar{O}\right)^{2}\right)^{1 / 2}\left(\sum_{1}^{n}\left(S_{i}-\bar{S}\right)^{2}\right)^{1 / 2}}\right]^{2}\end{array}$ & $0.5 \leq R^{2} \leq 1$ & Unsatisfactory & Steel and Torrie (1960) \\
\hline $\begin{array}{l}\text { Nash-Sutcliffe efficiency } \\
\qquad \mathrm{NSE}=1-\frac{\sum_{1}^{n}\left(O_{i}+S_{i}\right)^{2}}{\sum_{1}^{n}\left(O_{i}+\bar{O}\right)^{2}}\end{array}$ & $\begin{array}{l}0.65<\mathrm{NSE} \leq 0.75 \\
0.050<\mathrm{NSE} \leq 0.65 \\
0.40<\mathrm{NSE} \leq 0.50 \\
\mathrm{NSE} \leq 0.40 \\
0.4 \leq \mathrm{NSE} \leq 0.7\end{array}$ & $\begin{array}{l}\text { Very good } \\
\text { Good } \\
\text { Satisfactory } \\
\text { Acceptable } \\
\text { Unsatisfactory } \\
\text { Acceptable }\end{array}$ & $\begin{array}{l}\text { Boskidis et al. (2012) and Moriasi et al. } \\
\text { (2007) }\end{array}$ \\
\hline Percent bias $\mathrm{PBIAS}=\frac{\sum_{i=1}^{n}\left(O_{i}-S_{i}\right) \cdot 100}{\sum_{1}^{n}\left(O_{i}\right)}$ & $\begin{array}{l}\text { PBIAS }< \pm 10 \\
\pm 10 \leq \text { PBIAS }< \pm 15 \\
\pm 15 \leq \text { PBIAS }< \pm 25 \\
\text { PBIAS } \geq \pm 25\end{array}$ & $\begin{array}{l}\text { Very good } \\
\text { Good } \\
\text { Satisfactory } \\
\text { Unsatisfactory }\end{array}$ & Moriasi et al. (2007) \\
\hline $\begin{array}{l}\text { Root mean square error } \\
\qquad \mathrm{RSME}=\left[\frac{\left(\sum S_{i}-O_{i}\right)^{2}}{n}\right]^{-15}\end{array}$ & $\begin{array}{l}\text { Value below half the } \\
\text { standard deviation }\end{array}$ & Satisfactory & Singh et al. (2004) \\
\hline $\begin{array}{l}\text { Ratio of the RMSE to the stand- } \\
\text { ard deviation of the observation }\end{array}$ & $0.00 \leq \mathrm{RSR} \leq 0.50$ & Very good & Moriasi et al. (2007) \\
\hline $\mathrm{RSR}=\frac{\mathrm{RMSESTDEV}}{=} \frac{\left[\sqrt{\sum_{n}^{1}\left(O_{i}-S_{i}\right)^{2}}\right]}{\left.\sqrt{\sum_{n}^{1}\left(O_{i}-\bar{O}\right)^{2}}\right]}$ & $\begin{array}{l}0.50<\mathrm{RSR} \leq 0.60 \\
0.60<\mathrm{RSR} \leq 0.70 \\
\mathrm{RSR}>0.70\end{array}$ & $\begin{array}{l}\text { Good } \\
\text { Satisfactory } \\
\text { Unsatisfactory }\end{array}$ & \\
\hline P-factor & $0 \leq \mathrm{P}$-factor $\leq 1$ & $\begin{array}{l}1=\text { Good coincide } \\
0=\text { Not coincide }\end{array}$ & $\begin{array}{l}\text { Yang et al. (2008a, b) and Narsimlu et al. } \\
\text { (2015) }\end{array}$ \\
\hline R-factor $=\frac{\frac{1}{n} \sum_{t_{i=1}^{n}}^{n}\left(\gamma_{t_{i, 97.5 \%}^{M}}^{M}-\gamma_{t, 2.5 \%}^{M}\right)}{\sigma_{\mathrm{obs}}}$ & $0 \leq \mathrm{P}$-factor $\leq \infty$ & $\begin{array}{l}0=\text { Good certainty } \\
\infty=\text { Uncertainty }\end{array}$ & $\begin{array}{l}\text { Yang et al. (2008a, b) and Narsimlu et al. } \\
\text { (2015) }\end{array}$ \\
\hline
\end{tabular}

$i$ - time series of the measured and simulated pairs; $n$ —number of pairs of the measured and simulated variables; $O_{i}$-observational data; $S_{i}-$ simulated data; $\bar{O}-$ mean of the observational data

Table 2 Sensitive analysis of parameters in Sira station

\begin{tabular}{|c|c|c|c|c|c|c|}
\hline Index & Parameter & Definition & T-stat & $P$ value & Process & $\begin{array}{l}\text { Ranks of } \\
\text { sensitivity }\end{array}$ \\
\hline 1 & $\mathrm{CN} 2$ & SCS curve number for moisture condition II $^{\mathrm{a}}$ & 13.136 & 0.00 & Runoff & 1 \\
\hline 2 & ALPHA_BF & Base-flow alpha factors $\left(1\right.$ days $\left.^{-1}\right)$ & 12.472 & 0.00 & Groundwater & 2 \\
\hline 3 & CH_K2 & Channel-effective hydraulic conductivity $\left(\mathrm{mm} \mathrm{h}^{-1}\right)$ & 1.445 & 0.148 & Channel & 3 \\
\hline 4 & ESCO & Soil evaporation compensation factor & 0.268 & 0.788 & Soil & 4 \\
\hline 5 & CH_N2 & Manning's $n$ value for main channel ${ }^{\mathrm{a}}$ & 0.211 & 0.832 & Channel & 5 \\
\hline 6 & REVAPMN & $\begin{array}{l}\text { Threshold depth of water in the shallow aquifer for } \\
\text { 'revap' to occur (mm) }\end{array}$ & 0.185 & 0.853 & Groundwater & 6 \\
\hline 7 & GW-REVAP & Snowmelt base temperature $\left({ }^{\circ} \mathrm{C}\right)$ & 0.872 & 0.161 & Groundwater & 7 \\
\hline 8 & SOL-BD & Soil bulk density $\left(\mathrm{g} / \mathrm{cm}^{3}\right)$ & 0.130 & 0.896 & Soil & 8 \\
\hline
\end{tabular}

${ }^{\text {a }}$ T-stat is then used to identify the relative significance of each parameters. The sensitives given above are estimates of the average changes in the objective function resulting from changes in each parameters, while all other parameters are changing 


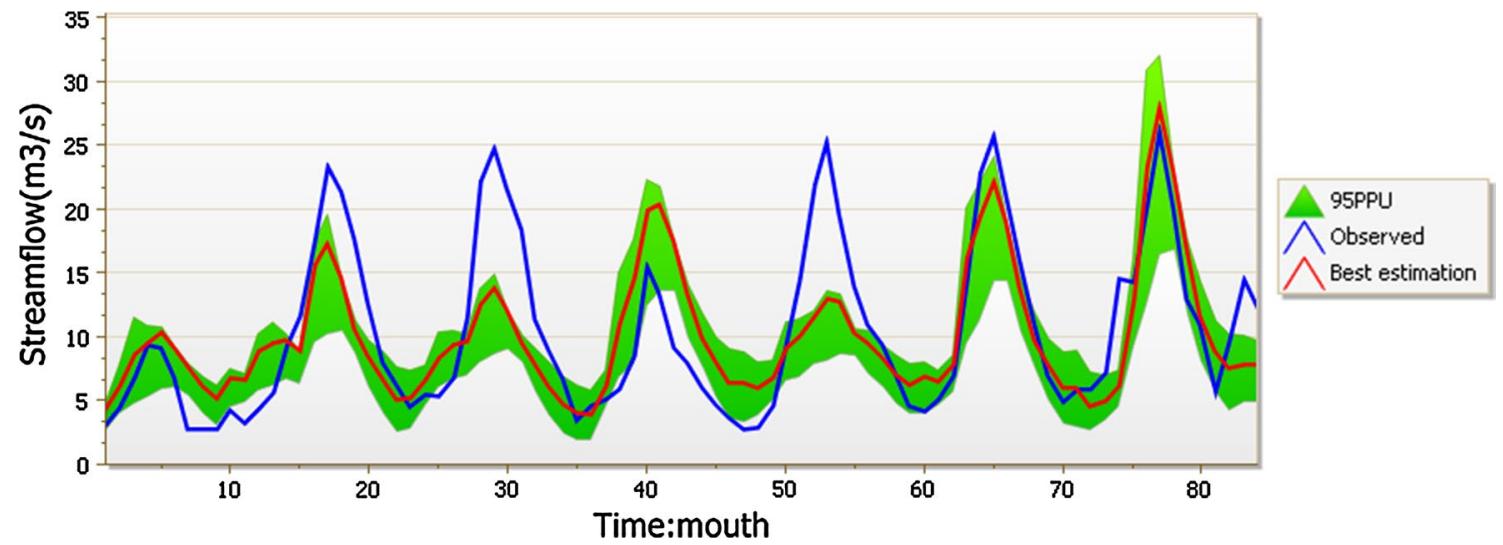

Fig. 5 The observed and estimated mean monthly discharge at Sira hydrometry station in calibration period (2000-2006)

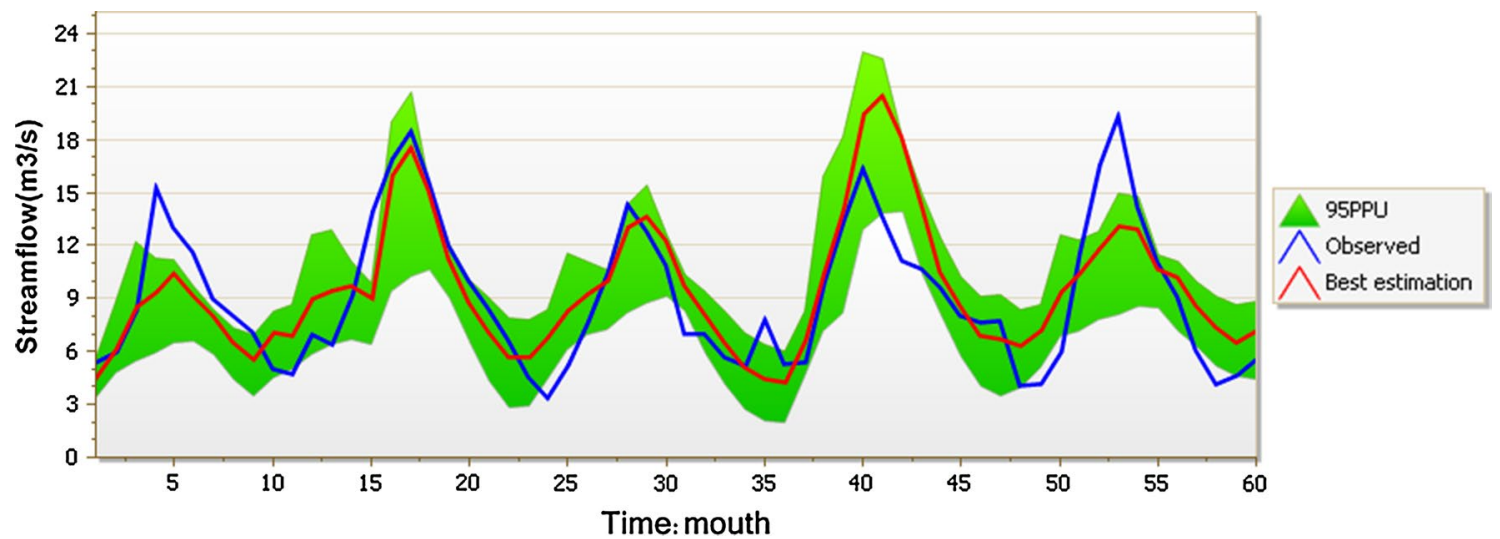

Fig. 6 The observed and estimated mean monthly discharge at Sira hydrometry station in calibration period (2007-2011)

Table 3 Statistical analysis of runoff simulation in calibration and validation periods

Fig. 7 Scatter plot of river stream flow for a calibration period (2000-2006) and b validation period (2007-2011)

\begin{tabular}{lllllllll}
\hline & Variable & $R^{2}$ & NSE & PBIAS & RMSE & RSR & P-factor & R-factor \\
\hline Calibration & FLOW_OUT & 0.58 & 0.57 & 0.2 & 0.435 & 0.6 & 0.36 & 0.36 \\
Validation & FLOW_OUT & 0.62 & 0.59 & 8.4 & 0.058 & 0.70 & 0.63 & 0.49 \\
\hline
\end{tabular}
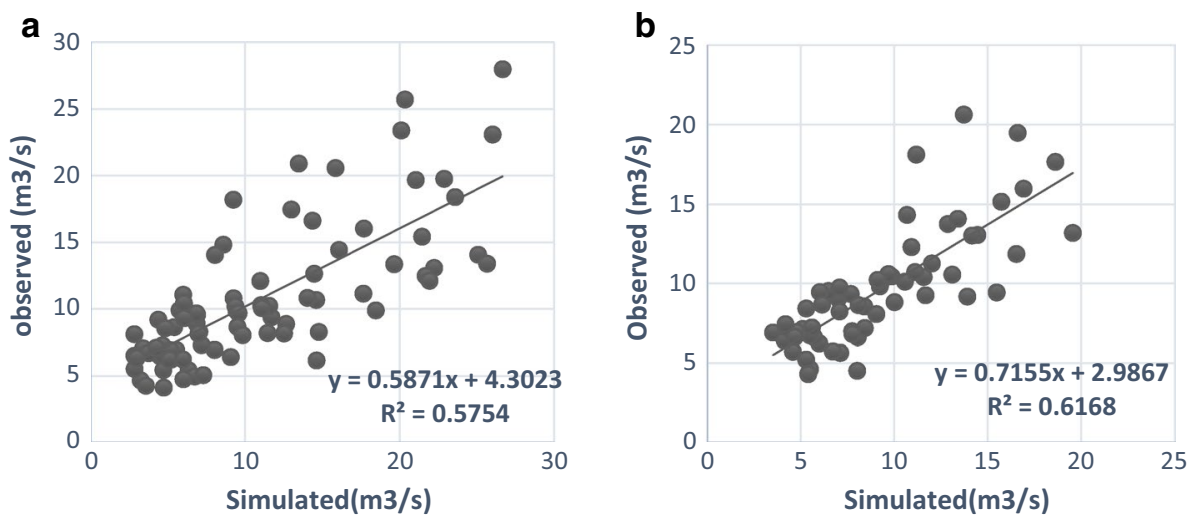
River catchment, hence reducing the quantity of model parameters that needed to be calibrated. In this study, eight sensitive parameters including CN2, ALPHA_BF, CH_K2, ESCO, CH_N2, REVAPMN, GW-REVAP and SOL-BD were used in a successful effort to decrease uncertainty.

Using the developed modeling and database platform, planners and decision makers will have access to a set of reliable tools to test any proposed scenarios of development within the different gauged or ungauged sub-catchments of the main basin and evaluate the impacts on surface water.

Acknowledgements Authors wish to acknowledge Soil Conservation and Watershed Management Institute (SCWMRI) for making data base accessible for this study.

Open Access This article is distributed under the terms of the Creative Commons Attribution 4.0 International License (http://creativeco mmons.org/licenses/by/4.0/), which permits unrestricted use, distribution, and reproduction in any medium, provided you give appropriate credit to the original author(s) and the source, provide a link to the Creative Commons license, and indicate if changes were made.

\section{References}

Abbaspour KC (2011) SWAT-CUP4: SWAT calibration and uncertainty programs - a user manual. Swiss Federal Institute of Aquatic Science and Technology, Eawag

Abbaspour KC, Johnson C, Van Genuchten MT (2004) Estimating uncertain flow and transport parameters using a sequential uncertainty fitting procedure. Vadose Zone J 3:1340-1352

Abbaspour KC, Yang J, Maximov I, Siber R, Bogner K, Mieleitner J, Zobrist J, Srinivasan R (2007a) Modelling hydrology and water quality in the prealpine/alpine Thur watershed using SWAT. J Hydrol 333(2-4):413-430

Abbaspour KC, Vejdani M, Haghighat S (2007b) SWAT-CUP calibration and uncertainty programs for SWAT. In: Proc. intl. congress on modelling and simulation (MODSIM'2007), Melbourne, Australia, pp 1603-1609

Abbaspour KC, Ashraf Vaghefi S, Srinivasan R (2018) A guideline for successful calibration and uncertainty analysis for soil and water assessment: a review of papers from the 2016 international SWAT conference. Water J 10:6. https://doi.org/10.3390/w10010006

American Society of Civil Engineers (1993) Criteria for evaluation of watershed models. J Irrig Drain Eng 119:429-442

Andersson L, Wilk J, Todd MC, Hughes DA, Earle A, Kniveton D, Layberry R, Savenije HHG (2006) Impact of climate change and development scenarios on flow patterns in the Okavango River. J Hydrol 331(1):43-57

Arnold JG, Fohrer N (2005) SWAT 2000: current capabilities and research opportunities in applied watershed modeling. Hydrol Process 19:563-572

Arnold JR, Williams AD, Nicks, Sammons NB (1990) A basin scale simulation model for soil and water resources management. Texas A \& M University Press, TX

Arnold JG, Srinivasan R, Muttiah RS, Williams JR (1998) large area hydrologic modeling and assessment, part I: model development. J Am Water Resour Assoc 34(1):73-89

Beven K, Binley A (1992) the future of distributed models-model calibration and uncertainty prediction. Hydrol Process 6(3):279-298
Bilondi MP, Abbaspour KC, Ghahraman B (2013) Application of three different calibration-uncertainty analysis methods in a semi-distributed rainfall-runoff model application. Middle East J Sci Res 15(9): 1255-1263

Boskidis I, Gikas GD, Sylaios GK, Tsihruntzis VA (2012) Hydrologic and water quality modeling of lower Nestos river basin. Water Resour Manag 26:3023-3051

De Girolamo AM, Lo Porto A (2012) Land use scenario development as a tool for watershed management within the Rio Mannu Basin. Land Use Policy 29:691-701

Debele B, Srinivasan R, Parlange JY (2008) Coupling upland watershed and downstream water hydrodynamic and water quality models (SWAT and CE-QUAL-W2) for better water resources management in complex river basins. Environ Model Assess $13: 135-153$

Du J, Rui H, Zuo T, Li Q, Zheng D, Chen A, Xu Y, Xu CY (2013) Hydrological simulation by SWAT model with fixed and varied parameterization approaches under land use changes. Water Resour Manag 27:2823-2838

Fukunaga DC, Cecílio RA, Zanetti SS, Oliveira LT, Caiado MAC (2015) Application of the SWAT hydrologic model to a tropical watershed at Brazil. Catena 125:206-213

Hosseini M (2010) Effect of landuse changes on surface runoff and suspended sediment yield of Taleghan Catchment, Iran. Ph.D. Thesis, University Putra Malaysia

Hosseini M, Ashraf MA (2015) Application of the SWAT model for water components separation in Iran. Springer, Tokyo

Hosseini M, Ghafouri M, Tabatabaei MR, Goodarzi M, AbdeKolahch A (2012) Effects of land use changes on water balance in Taleghan Catchment. J Agric Sci Technol 14:1159-1172

Huang J, Zhou P, Zhou Z, Huang Y (2013) Assessing the influence of land use and land cover datasets with different points in time and levels of detail on watershed modeling in the north river watershed, China. Int J Environ Res Public Health 10:144-157

Huang SH, Krysanova V, Hattermann F (2015) Projections of climate change impacts on floods and droughts in Germany using an ensemble of climate change scenarios. Reg Environ Change 15(3):461-473

Krysanova V, Srinivasan R (2015) Assessment of climate and land use change impacts with SWAT. Reg Environ Change 15:431-434

Kuczera G, Parent E (1998) Monte Carlo assessment of parameter uncertainty in conceptual catchment models: the Metropolis algorithm. J Hydrol 211(1-4):69-85

Lin B, Chen X, Yao H, Chen Y, Liu M, Gao L, James A (2015) Analyses of landuse change impacts on catchment runoff using different time indicators based on SWAT model. Ecol Ind 58:55-63

Loague K, Green RE (1991) Statistical and graphical methods for evaluating solute transport models: overview and application. $\mathrm{J}$ Contam Hydrol 7:51-73

Monteith JL (1965) Evaporation and the environment. In: 19th Symposia of the society for experimental biology, vol 19, pp 205-235

Moriasi DN, Arnold JG, Van Liew MW, Bingner RL, Harmel RD, Veith TL (2007) Model evaluation guidelines for systematic quantification of accuracy in watershed simulations. Am Soc Agric Biol Eng 50:885-900

Narsimlu B, Gosain AK, Chahar BR, Singh SK, Srivastava PK (2015) SWAT model calibration and uncertainty analysis for streamflow prediction in the Kunwari river basin, India, using sequential uncertainty fitting. Environ Processes 2:79-95

Nash JE, Sutcliffe JV (1970) River flow forecasting through conceptual model. Part 1-a discussion of principles. J Hydrol 10:282-290

Neitsch SL, Arnold JG, Kiniry JR, Williams JR (2011) Soil and water assessment tool: theoretical documentation-version 2009. Texas Water Resources Institute Technical Report No. 406. Agricultural Research Service (USDA) and Texas Agricultural Experiment Station, Texas A\&M University, Temple

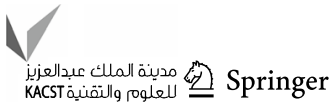


Niu J, Sivakumar B (2014) Study of runoff response to land use change in the east river basin in south China. Stoch Environ Res Risk Assess 28(4):857-865

Nyeko M (2015) Hydrologic modelling of data scarce basin with SWAT model capabilities and limitations. Water Resour Manag 29:81-94

SCWMRI (2002) Atlas land use map for Iran. Soil Conservation and Watershed Management Institute

Shen Z, Hong Q, Yu H, Niu J (2010) Parameter uncertainty analysis of non-point source pollution from different land use types. Sci Total Environ 408:1971-1978

Singh SK, Dutta S (2016) Effect of observational uncertainty on hydrological modeling. In: Proc. 56th New Zealand hydrological society's the water and infrastructure and environmental conference, 28 Nov-2 Dec 2016, Queenstown, New Zealand

Singh VP, Woolhiser DA (2002) Mathematical modeling of watershed hydrology. J Hydrol Eng 7:270-292

Singh J, Knapp HV, Demissie M (2004) Hydrologic modeling of the Iroquois river watershed using HSPF and SWAT. Illinois Department of Natural Resources and the Illinois State Geological Survey. Illinois State Water Survey Contract Report 2004-08

Steel RGD, Torrie JH (1960) Principles and procedures of statistics. McGraw-Hill Book Company, New York, p 481

USDA Soil Conservation Service (1972) National engineering handbook, section 4, hydrology. USDA Soil Conservation Service, Washington DC

Van Griensven A, Meixner T (2006) Methods to quantify and identify the sources of uncertainty for river basin water quality models. Water Sci Technol 53(1):51-59

Van Griensven A, Meixner T, Grunwald S, Bishop T, Diluzio M, Srinivasan R (2007) A global sensitivity analysis tool for the parameters of multi-variable catchment models. J Hydrol 324:10-23

Veith TL, Ghebremichael LT (2009) How to: applying and interpreting the SWAT auto-calibration tools. In: Proceedings of the 5th international SWAT conference, Boulder, 5-7 August 2009, pp. 26-33

Vilaysanea B, Takaraa K, Luob P, Akkharathc I, Duan W (2015) Hydrological stream flow modelling for calibration and uncertainty analysis using SWAT model in the Xedone river basin, Lao PDR. Procedia Environ Sci 28:380-390
Vrugt JA, TerBraak CJ, Clark MP, Hyman JM, Robinson BA (2008) Treatment of input uncertainty in hydrologic modeling: doing hydrology backward with Markov chain Monte Carlo simulation. Water Resour Res 44:W00B09. https://doi.org/10.1029/2007w r006720

Wang X, Melesse AM, Yang W (2006) Influences of potential evapotranspiration estimation methods on SWAT's hydrologic simulation in a northwestern Minnesota watershed. Trans ASABE 49(6): 1755-1771

Winchell M, Srinivasan R, Di Luzio JM (2009) ArcSWAT 2.3.4 interface for SWAT2005: user's guide. Blackland Research Center: Texas Agricultural Experiment Station, Temple, p 465

Wurbs RA (1998) Dissemination of generalized water resources models in the United States. Water Int 23:190-198

Yang J, Reichert P, Abbaspour KC, Xia J, Yang H (2008a) Comparing uncertainty analysis techniques for a SWAT application to Chaohe basin in China. J Hydrol 358(1-2):1-23

Yang J, Abbaspour KC, Reichert P, Yang H (2008b) Comparing uncertainty analysis techniques for a SWAT application to Chaohe basin in China. J Hydrol 358(1-2):1-23

Yang SK, Jung WY, Han WK, Chung IM (2012) Impact of land-use changes on stream runoff in Jeju Island, Korea. Afr J Agric Res 7(46):6097-6109

Zhang Y, Xia J, Shao Q, Zhai X (2011) Water quantity and quality simulation by improved SWAT in highly regulated Huai river basin of China. Stoch Environ Res Risk Assess 27(1):11-27

Zhang A, Zhang C, Fu G, Wang B, Bao Z, Zheng H (2012) Assessments of impacts of climate change and human activities on runoff with SWAT for the Huifa river basin, northeast China. Water Resour Manag 26:2199-2217

Publisher's Note Springer Nature remains neutral with regard to jurisdictional claims in published maps and institutional affiliations. 